\title{
Promega and Roche take up battle over PCR patents
}

\section{San Francisco}

The Swiss-based pharmaceutical company

Hoffman-LaRoche is facing a series of legal hearings over the validity of its two

key patents on the polymerase chain reaction (PCR). The process will culminate in a trial in a federal court in October next year.

Last week, a judge in San Francisco announced the timescale for the proceedings, following a ruling that Roche's patent on the enzyme Taq polymerase - an essential component of PCR described in the patent application — had been fraudulently obtained (see Nature 402, 709; 1999).

The proceedings are the latest stage of a long-running legal battle between Roche and the Wisconsin-based biotechnology company Promega over issues associated with PCR, which is used to amplify small quantities of DNA. Next year's trial will also address Roche's allegation that Promega, by selling its own unlicensed native Taq, has induced researchers to violate Roche patents and licence agreements.

According to Brenda Furlough,
Promega's general counsel, the company's challenge to Roche's PCR patent is based on its claims that the US Patent and Trademark Office (PTO) was not told about certain previous discoveries when the PCR patent was sought more than a decade ago.

But Melinda Griffin, general counsel for Roche Molecular Systems in Alameda, California, says that Promega's claims are groundless, and that the firm expects to defeat all of Promega's challenges, and win its patent-infringement claims against the Wisconsin company.

Court records show that Promega will make its initial disclosures in April this year on what 'prior art' it claims is involved in the disclosures to the PTO that it is challenging. Furlough declines to provide details of the evidence that it intends to produce.

The PCR patents in dispute were acquired by Roche when the company purchased the Cetus Corp. of California in 1991, where Kary Mullis was working when he invented PCR - for which he won a
Nobel prize. In a previous unrelated legal battle, Roche fought the DuPont Corp. over the rights to PCR.

Promega's challenge, and Roche's infringement claims against Promega, were held in abeyance while the two companies battled over the Taq patent. Last December, US District Judge Vaughn Walker ruled that a Roche patent for native Taq was obtained through eight instances of fraud.

If Walker's ruling that the patent is 'unenforceable' stands up on appeal, Roche's patent for native Taq would be invalidated. At a hearing last week, Walker ruled that Roche can go forward with an expedited appeal on the ruling, despite Promega's call for other issues to be decided first. "We are very pleased the judge granted our request for an appeal now," says Griffin.

The appeal will be addressed to the Court of Appeals in Washington DC. If the court agrees to hear the appeal, a decision could take 18 months.

Roche's Thomas White said that he was confident the defence of the recombinant Taq patent would succeed.

\section{Funding woes spell doom for US radio dish}

Washington

One of radioastronomy's venerable telescopes - and the only millimetre-wavelength instrument that serves the entire US research community - will be shut down in July, the victim of continuing tight budgets for the National Radio Astronomy Observatory (NRAO).

The 12-Meter Telescope on Kitt Peak, Arizona, was built in 1967 and upgraded in 1984. It was a pioneering instrument in the study of interstellar molecules, and is still used by more than 150 visiting scientists a year, with staff on hand to assist with observations.

The NRAO, which runs several US radioastronomy facilities for the National Science Foundation, had hoped to keep it operational until the far more powerful Atacama Large Millimeter Array (ALMA) comes online later this decade. But years of flat funding have strained resources to the point where keeping the older telescope going is no longer an option, says Paul Vanden Bout, director of the NRAO, which is based in Charlottesville, Virginia.

Although Vanden Bout says the decision to close the telescope "wasn't strictly a budgetary matter", he admits that "the scope of our activities has exceeded our resources". A total of 24 NRAO staff in Tucson will be affected by the closure. About half are

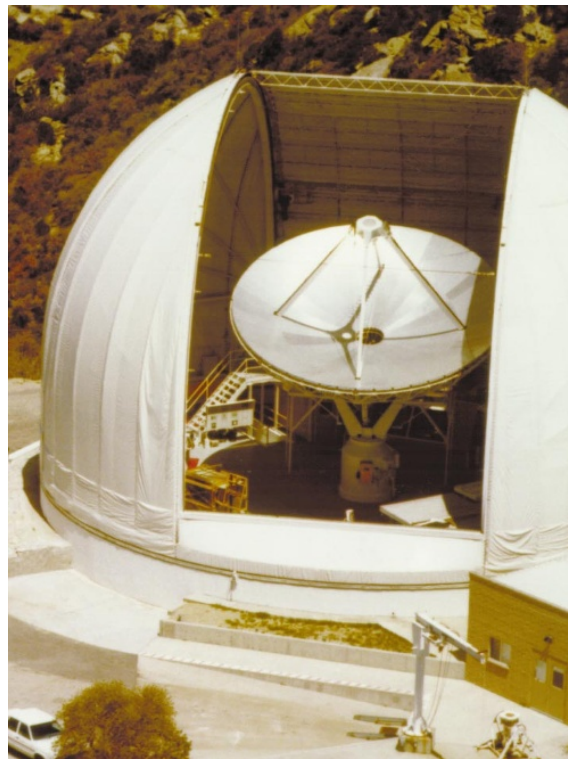

Turn off, tune out: Kitt Peak's 12-Meter Telescope will close before its replacement is ready to open.

expected to shift over to work on ALMA, but others will be out of a job, he says. The move is expected to save around \$2 million a year in operational costs.

The NRAO, which also operates the Very Large Array in New Mexico and the Very Large Baseline Array of ten dishes located in different states, has requested \$32.5 million for next year, the same as last year. With ALMA on the way, a flat budget would be difficult enough to manage. But the NRAO has another cloud hanging over it in the form of a $\$ 29$ million claim by COMSAT, the contractor building the new Green Bank Telescope in West Virginia (see Nature 384, 505; 1996).

COMSAT has charged that cost overruns on the telescope are the fault of the NRAO and its parent organization, Associated Universities, Inc. The case has gone to binding arbitration, with a decision expected this autumn. If the NRAO is forced to pay a substantial amount of the $\$ 29$ million, it would be a severe financial blow.

Vanden Bout says he is confident that NRAO lawyers made a compelling case to the arbitrators, and denies that the decision to close the telescope had anything to do with bracing for an unfavourable decision in the COMSAT dispute. The long-delayed $\$ 74.5$ million Green Bank Telescope is finally nearing completion, he says, with operation scheduled to begin by late summer or autumn.

Radioastronomers, meanwhile, are mourning the loss of the 12-metre telescope. Carl Heiles of the University of California at Berkeley calls it a "real blow", and worries that it will make it even more difficult to attract and train graduate students in millimetre-wavelength astronomy. Tony Reichhardt 